\title{
DIFFERENCES IN PORTUGUESE CREDIT INSTITUTIONS' LENDING AND INVESTMENT BEHAVIOUR IN A TIME OF SLUMP
}

\author{
by \\ Paula CABO* \\ Polytechnic Institute of Bragança, Portugal \\ and \\ João REBELO* \\ University of Tras-Os-Montes and Alto Douro, Vila Real, Portugal
}

\begin{abstract}
The purpose of this paper is to investigate the influence of the different property rights models of credit institutions (public, private, cooperative or mutual) in their credit policy and investment behaviour and in response to the current crisis and regulatory framework adjustments. Taking Portuguese credit institutions as the object, it concludes that overall banks' business models are qualitatively identical and their lending and investment behaviours are similar, except for the saver profile of cooperative banks and the deeper focus on loans to customers to the detriment of financial investments of the mutual savings banks. Moreover, the reactions to the crisis were equivalent, except for the state-owned banks, which presented the most favourable reaction, albeit not deep enough to be significant.
\end{abstract}

\section{Unterschiede im Kreditvergabe- und Investitionsverhalten portugiesischer Kreditinstitute in einer Zeit der Krise}

Ziel dieses Beitrags ist es, den Einfluss der verschiedenen Property Rights Modelle von Kreditinstituten (öffentliche, private, genossenschaftliche oder auf Gegenseitigkeit basierende) auf deren Kreditpolitik und Investitionsverhalten angesichts der gegenwärtigen Krise und der Änderungen des regulatorischen Rahmens zu untersuchen. Betrachtet man die portugiesischen Kreditinstitute, kommt man zu dem Schluss, dass allgemein die Geschäftsmodelle der Banken identisch sind und ihr Investitionsverhalten ähnlich ist, mit Ausnahme der Sparerprofile von Genossenschaftsbanken und des stärkeren Fokus auf Kundendarlehen statt auf Finanzanlagen bei den Spar- und Darlehenskassen auf Gegenseitigkeit. Auch waren die Reaktionen auf die Krise gleichartig, mit Ausnahme der staatlichen Banken, die am positivsten reagierten, allerdings nicht durchgreifend genug, um signifikant zu sein.

E-mails: paulacabo@ipb.pt; jrebelo@utad.pt 


\title{
Las diferencias de comportamiento en las políticas de préstamo y inversión de las instituciones de crédito portuguesas en una época de recesión
}

\begin{abstract}
El propósito de este trabajo es investigar la influencia de los diferentes modelos de los derechos de propiedad de las instituciones de crédito (pública, privada, cooperativa o mutua) en su política de crédito y comportamiento de inversión y en respuesta a la crisis actual y a los ajustes del marco regulatorio. Tomando las entidades de crédito portuguesas como objeto llega a la conclusión de que, globalmente, los bancos siguen un modelo de negocio cualitativamente idéntico y el comportamiento de préstamo e inversión son similares, excepto los bancos cooperativos que ostentan un perfil de ahorro, y el banco de ahorro mutuo que presenta un enfoque más profundo en préstamos a clientes en detrimento de las inversiones financieras. Por otra parte, las reacciones a la crisis eran equivalentes, a excepción del banco de propiedad estatal, que presentó la reacción más favorable, aunque no suficientemente profunda como para ser estáticamente significativa.
\end{abstract}

\section{Les différences de comportement dans les politiques de prêt et d'investissement des institutions de crédit portuguaises en temps de récession}

L'objectif de cet article est d'étudier l'influence des différents modèles des droits de propriété des institutions de crédit (publiques, privées, coopératives ou mutuelles) sur leur politique de crédit et le comportement d'investissement, dans le contexte actuel de crise et d'ajustement du cadre régulateur. Considérant les institutions de crédit portugaises, nous arrivons à la conclusion que, globalement, les banques suivent un "business model" qualitativement identique. Par ailleurs leurs comportements de prêt et d'investissement sont similaires, excepté pour les banques coopératives qui montrent un comportement davantage tourné vers l'épargne et pour les banques d'épargne mutuelles qui accordent plus d'importance aux prêts des clients qu'aux investissements financiers. En outre, les réactions à la crise étaient équivalentes, à l'exception des banques publiques qui présentaient la réaction la plus favorable bien que la différence ne soit pas suffisamment importante pour être statistiquement significative.

\section{Introduction}

The 2008 global crisis and the European sovereign debt crisis that followed it produced, among other consequences, general mistrust in financial institutions. Banks' greedy investment policy led them into trouble and taxpayers paid the bill, with governments ending up bailing them out. These events encouraged the debate on the economic role of banks and other credit institutions as rational economic agents answering to society needs and key players in the challenges of economic and social development.

The Portuguese financial system includes credit institutions and financial companies. Among the credit institutions, the domestic ones dominate the market; particularly, a state-owned bank, several private investor-owned firm (IOF) banks, a mutual savings bank and an agricultural credit cooperative banking system stand out. In Portugal, like in many other countries, cooperative and mutual savings banks, which, in the past, were not considered the most efficient or innovative, were generally able to avoid many of the mistakes made by larger IOF banks and have weathered the crisis better, proving 
that they are (still) a valid business alternative. Consequently, while larger universal banks exhibited overall negative profits in 2011, savings and cooperative banks were among the few banks presenting positive net returns. But what are these institutions' distinctive features? Why they are standing firm and even, in some cases, increasing their market shares, when others are drowning in the crisis and struggling to survive? Furthermore, what can the other financial institutions learn from them?

By allocating capital to individuals and businesses that want to make productive use out of it, financial institutions create social value and, in this way, play an important role in the economic and social development of a country or region. However, the financial crisis of 2008 is the latest proof that finance today takes on a wholly different and less socially conscious meaning. In particular, in Portugal, during this crisis, the financial institutions often played the role of the 'bad guy': in the early days because of their recklessness and somewhat pushy credit-granting practices, which contributed to the over-indebtedness of Portuguese families; nowadays because of their restrictive lending policies, which are strangling small and medium-sized enterprises while the press reveals banks' earnings with Portuguese sovereign debt. The general public opinion judges banks' behaviour severely, and politicians have made banks' granting of loans strategy part of their political agenda. Meanwhile, banks are making efforts contrary to this view by developing and publicizing partnerships and programmes to finance microcredit and small business enterprises.

The purpose of this paper is to investigate the influence of the different property rights models of credit institutions (public, private, cooperative or mutual) on their lending and investment behaviour and in response to the current crisis and regulatory framework adjustments. In methodological terms, the paper examines the banking situation in Portugal by using financial indicators, prior to and after the 2008 financial crisis.

The paper is organized as follows: section 2 consists of a literature review on credit institutions' ownership and their lending and investment behaviours; section 3 presents the regulatory framework and some historic data on the Portuguese banking system; section 4 includes the empirical work; and section 5 concludes.

\section{Credit institutions' ownership and lending and investment behaviour: a literature review}

The financial system and the banks within it play a crucial role in the economy, enabling people to invest their resources to earn income in the future and increasing investment and entrepreneurship. The modern theory of financial intermediation explains the existence of financial institutions by the presence of certain forms of market imperfection, for example asymmetric information.

The rationale of financial intermediaries relies on their effectiveness and efficiency in reducing these imperfections more effectively and at a lower cost than individual borrowers or lenders can, thanks to their structure and organization, allowing them to reduce the risks of investment and the costs of information and ultimately allowing better allocation of resources (Benston and Smith 1976, Goodhart 1989). Indeed, financial intermediaries, through screening and monitoring practices, are able to minimize information costs efficiently by exploiting economies of scale in information collection and 
production, avoiding free-rider problems and the duplication of monitoring by individuals and with the advantage that no 'private' information is disclosed, thus protecting borrowers' privacy (Boscia and Di Salvo 2009).

Traditional banks (investor-owned and profit-maximizing) are one of the most ancient forms of capitalistic organization, existing well before the Industrial Revolution. With the global expansion of market economies around the world, other organizational forms, like cooperative and mutual savings banks, have emerged, competing successfully, mainly in retail banking. This variety of organizational forms may be explained by both government regulation and other forms of protection or by the specific market failures (asymmetric information) that are successfully addressed by these different organizational forms. In this way, the recent economic literature has argued that ownership structures and organizational forms are indeed an endogenous result of the rational choices made by agents facing market failures (Boscia and Di Salvo 2009, Cabo 2012, Cuevas and Fisher 2006). Cuevas and Fischer (2006) identified three complementary theories to understand how institutional features deal with market failures: the agency theory, the property rights theory and the transaction costs theory. The agency theory suggests that a cooperative or mutual bank experiences lower agency costs mainly due to the 'peer-monitoring' mechanism, which reduces asymmetric information and monitoring costs, and to the alignment of members' and management risk behaviour, as a consequence of the banks' mutuality feature. Moreover, a cooperative bank may present lower agency costs as a consequence of its more efficient internal decision-making process, since the chain of decisions is usually shorter than in IOFs, reducing the level of separation between ownership and management (Boscia and Di Salvo 2009, Bunger 2009, Fonteyne 2007, Kane and Hendershott 1996, Stiglitz 1990). The property rights theory suggests that the separation between owners and managers in a cooperative or mutual bank may be reduced by appointing only members as managers and fostering members' participation in the annual general assembly and other business meetings (Boscia and Di Salvo 2009). The transaction costs economics indicate that the proximity of the bank and the peculiar nature of the customer relationship give the cooperative or mutual bank some transaction-cost-specific advantages relative to IOFs (Boscia and Di Salvo 2009, De Bruyn and Ferri 2005, Fonteyne 2007).

The distinct policies of credit granting and financial investment behaviour (Ferri et al. 2014) due to the differences in the credit institutions' mission/ownership form (for profit or not for profit, private or public) suggest that stakeholder banks not only have a business model that is different from that of shareholder banks, but also differ from them in terms of their business objective and ownership structure (Beck et al. 2009, Hesse and Cihák 2007). Shareholder banks' or IOF banks' primary objective is to maximize the profits and capital return to shareholders, and they do so often through speculative trading activities on the financial market (Paulet and Relano 2010). On the contrary, stakeholder banks, such as cooperative and mutual savings banks, being not-for-profit institutions, pursue a twofold objective, providing the community (members/customers and local population) with both economic and social benefits. Therefore, they should concentrate on less risky activities, such as retail banking (Hesse and Cihák 2007), privileging the social or regional dimension of the projects that they finance. Stakeholder banks are more involved in relationship lending and thus hold longer-term objective functions than shareholder banks and could be more prone to smoothing out financial constraints for their borrowers in order to maximize the long-term values of their borrower-lender 
relationships (Boot 2000, Petersen and Rajan 1994). Stakeholder banks could thus be more willing to sacrifice other assets in order to keep their lending volume intact. On the contrary, shareholder banks, while focusing on maximizing profits, could then cut back lending more easily if that would result in lower short-term costs (following the theory of the bank capital channel). On the other hand, Köhler (2014), analyzing the impact of business models on bank stability, stated that banks will be significantly more stable and profitable if they increase their share of non-interest income (financial investment), indicating that substantial benefits are to be gained from income diversification, particularly for savings and cooperative banks, which are traditionally more retail-oriented credit institutions.

Moreover, the government can use state-controlled banks to compensate for market failures, such as externalities, that can lead to a lack of financing for socially profitable projects (Sapienza 2004). Thus, a public bank should incorporate the government guidelines for the economic and social development of the country into its mission. In this way, although still being for profit, public banks should behave differently from IOF banks, respecting the 'less profit, more sense' principle. Indeed, it is supposed that statecontrolled banks boost their lending during a crisis to support the economy (Fungáčová et al. 2013), as the objective function of state-controlled banks is likely to include stabilization of the economy. As a consequence, the government may be willing to limit a credit contraction in troubled times.

The literature contains numerous instances concerning the differences in bank lending and investment policies across banks of different ownership forms. Gambacorta and Mistrulli (2004) studied the response to monetary policy and business cycles of Italian banks, concluding that non-cooperative banks behave more pro-cyclically when supplying credit, due to their stronger dependency on non-deposit forms of external funds and their lower proportion of long-term lending relationships. Ferri et al. (2014), analyzing the differences in bank lending supply responses to changes in monetary policy, found that stakeholder banks try to smooth out the financial conditions for their customers in order to maintain longer-term borrower-lender relationships by conducting less procyclical loan supply policies and being less strict about credit standards, irrespective of the economic or financial situation. Further, this tendency was stronger for cooperative banks during the recent crisis relative to savings banks. Their results indicate that the presence of stakeholder-oriented banks can dampen the volatility of lending. The authors state that this finding, together with other evidence on the positive effects coming from the presence of stakeholder banks, should lead to the reconsideration of the role of stakeholder banks in a modern financial system. Micco and Panizza (2006) found that the lending of state-owned banks is less sensitive to macroeconomic shocks than that of private banks. In addition, Bertay et al. (2012) concluded that lending by state-owned banks is less procyclical than lending by private banks, especially in countries with good governance. These findings reinforce the view that state-owned banks consider macroeconomic stabilization in their objective function.

\section{Overview of the Portuguese banking sector}

The activity of institutions operating in the Portuguese financial system is ruled by the Legal Framework of Credit Institutions and Financial Companies (RGICSF), 
approved by Decree-Law No. 298/92 and amended subsequently, which lays down the conditions for the taking up and pursuit of the business of credit institutions and financial companies. Among credit institutions, companies engaging in business activity that consists of accepting deposits and other repayable funds from the public in order to invest them on their own account by granting loans, banks, savings banks and agricultural credit cooperative banks stand out. The latter of these, given their mutuality feature and specific purpose, are subject to a specific law, namely the Legal Framework of Savings Banks, approved by the Decree-Law No. 136/79 and posterior amendments for mutual savings banks, and the Legal Framework of Mutual Agricultural Credit and Mutual Agricultural Credit Banks, approved by Decree-Law No 24/91 and subsequently amended.

Overall, in 2011, Portuguese financial service activities (except insurance and pension funding and including the activities carried out by the Bank of Portugal) contributed to approximately $6 \%$ of the national gross value added. This weight is relatively high when compared with other euro area countries (APB 2012a). Table 1 presents a picture of the Portuguese banking system by origin/type of legal structure. Institutions set up under Portuguese law, especially domestic institutions, predominated in the total number and value of aggregate assets in all the size categories and engaged in multiproduct activity (APB 2012b).

Table 1 - The Portuguese banking system at 31 December 2011

\begin{tabular}{lr}
\hline By No. of Entities & 69 \\
Domestic & 9 \\
Subsidiary & 27 \\
Branch office & 105 \\
Total & \\
By Assets (Million $€$ ) & 401,190 \\
Domestic & 68,733 \\
Subsidiary & 43,246 \\
Branch office & 513,169 \\
$\quad$ Total
\end{tabular}

Source: Adapted from APB (2012b)

With regard to size, measured by the value of assets, the banking system is relatively asymmetrical (Figure 1): $94.3 \%$ of the aggregate assets of the Portuguese banking system are concentrated in 13 large and medium-sized institutions, while the remaining 20 small financial institutions together have a market share of only $5.7 \%$.

Despite the concentration of assets, the analysis of the credit institutions' branch network shows that there is considerable homogeneity between the number of each credit institution's branches, which points to the existence of greater competition between the institutions in the retail banking market and in attracting business through the branch network as opposed to other types of banking activity (APB 2012b).

The year 2011 was especially difficult for Portugal, with several external and internal circumstances having repercussions for the banking industry, especially for banks' business activity, funding and performance, thus explaining the negative returns presented by the overall banking system. Particularly, the structural imbalances in the Portuguese economy, reflected by high levels of public and private borrowing in a context 


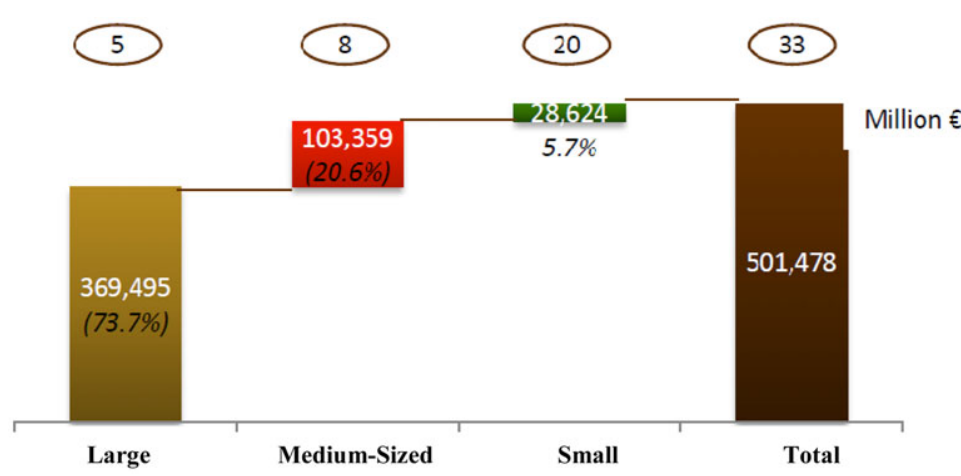

Figure 1 - Concentration of aggregate assets by size of credit institutions at 31 December 2011

Source: APB (2012b)

of slim economic growth and deteriorating perception of the credit risk of sovereign debt, made Portugal's finance conditions in the international markets too severe and obliged the country to request foreign financial assistance in April 2011. From mid-year, the Economic Adjustment Programme (EAP) negotiated with the Troika (International Monetary Fund, European Union and European Central Bank) and imposed an extra need for the banking institutions to adjust their activity. This programme obliged banks to fulfil a number of new prudential requirements: a) increasing their minimum core tier 1 capital ratio ${ }^{1}$ to $9 \%$ and $10 \%$ by the end of 2011 and 2012 , respectively; b) reducing their transformation ratio $^{2}$ to $120 \%$ by December 2014 ; c) conducting inspections to assess their credit portfolios as of 30 June 2011 as part of the Banco de Portugal Special Inspection Programme for the eight largest banking groups; and (d) reviewing the system for the reorganization and winding-up of financial institutions set out in the RGICSF in order to strengthen bank recovery and resolution mechanisms (APB 2012b, c).

Additionally, the EAP reinforced the support for Portuguese banks with: a) the provision of an extraordinary state guarantee on bond issues by the banking sector, while the EAP laid down the possibility of banks issuing state-guaranteed debt to a maximum of 35 billion euros; and b) the availability of a fund for recapitalization of credit institutions to the amount of 12 billion euros. At the same time, due to the need for fiscal consolidation, the government introduced a levy on the banking sector for the highest-risk liabilities on the balance sheet and decreed a partial transfer of the pension funds of some institutions to Social Security (APB 2012b, c).

Additionally, as was to be expected, while on the one hand the need to reduce the transformation ratio required an increase in efforts to attract customer deposits, on the other hand it placed pressure on the granting of loans. Furthermore, the requirement to increase solvency levels accentuated the need to deleverage banking activity, as the difficulty in recourse to the capital markets in normal conditions meant that the financial

1 The core tier 1 capital ratio is a measure of bank solvency, defined by the relation between a bank's own funds and its total weighted risk assets.

2 Or the loans-to-deposits ratio, which reflects banks' ability to convert customers' deposits into loans. 
institutions had to achieve this goal by selling non-core assets, reducing their credit portfolio and/or reducing the average risk of their assets. Because of these limitations, the banking institutions' volume of business activity contracted, opposing the expansion trend of previous years. Indeed, contrary to what occurred in the euro area, the 2008 financial crisis did not slow down the total assets growth of Portuguese banks. However, Portuguese banks started their deleveraging process after the EAP started. In terms of balance sheet structure, Portuguese banking institutions also underwent remarkable changes after 2006, as shown in Table 2.

Table 2 - The Portuguese banking sector's structural evolution ${ }^{3}$ (2006-2011) (thousand $€$ )

\begin{tabular}{crrrrrr}
\hline & 2006 & 2007 & 2008 & 2009 & 2010 & 2011 \\
\hline Gross Loans & $228,031,528$ & $301,118,231$ & $332,202,095$ & $333,067,974$ & $333,587,057$ & $313,951,905$ \\
As\% of Total Assets & 67.45 & 66.40 & 68.88 & 64.61 & 62.09 & 60.76 \\
Financial Investments & $38,766,135$ & $53,474,997$ & $53,891,671$ & $72,223,977$ & $92,167,250$ & $80,543,343$ \\
As\% of Total Assets & 11.47 & 11.79 & 11.17 & 14.01 & 17.15 \\
Deposits from Central Banks & $1,739,296$ & $5,731,452$ & $14,407,383$ & $19,418,981$ & $48,788,176$ & $50,723,175$ \\
As\% of Total Liabilities & 0.55 & 1.35 & 3.17 & 4.03 & 9.71 \\
Deposits from Customers & $156,633,328$ & $201,880,371$ & $219,899,428$ & $220,503,545$ & $232,399,699$ & $246,741,624$ \\
As\% of Total Liabilities & 49.51 & 47.73 & 48.44 & 45.74 & 46.23 & 50.40 \\
\hline
\end{tabular}

Source: Bank of Portugal's Statistical Interactive Database, own calculations

The financial institutions' borrowing structure (equity and liabilities), in the 20062011 period, continued to be based on deposits from customers, which contributed more than $50 \%$ to their total borrowing in 2011. Moreover, the analysis of funding evolution shows an increase in the importance of the deposits from customers and from central banks after the 2008 financial crisis. The main reasons for this performance by customers' deposits are: a) the uncertainty in Portugal and the rest of Europe, which has generated a preference for lower-risk alternatives on the part of consumers of financial products and services; b) financial institutions' strong need to attract more stable funds, essentially because of the EAP requirement to reduce the transformation ratio, and the Portuguese financial institutions' difficulties in accessing the wholesale finance markets, which led to intensification of the competition to attract deposits. The increase in funding from central banks reflects the borrowing from the Eurosystem, also a result of the Portuguese financial institutions' difficulties in accessing the wholesale finance markets.

The asset structure shows that, in spite of the importance of loans and advances to customers, their weight decreased during the period of analysis. The EAP recommendation to reduce the transformation ratio and the deleveraging process of banking activity affected the granting of credit, as the risk assessment criteria and loan criteria become more selective and restrictive. These factors, combined with a natural contraction in the demand for credit by the non-financial private sector due to the recession, resulted in a decrease in credit volumes' trend (Figure 2).

3 Values expressed at current prices; the deflator of the gross domestic product in the period was 3.2 for 2007, 1.6 for 2008, 0.5 for 2009, 1.1 for 2010 and 1.0 for 2011 . 


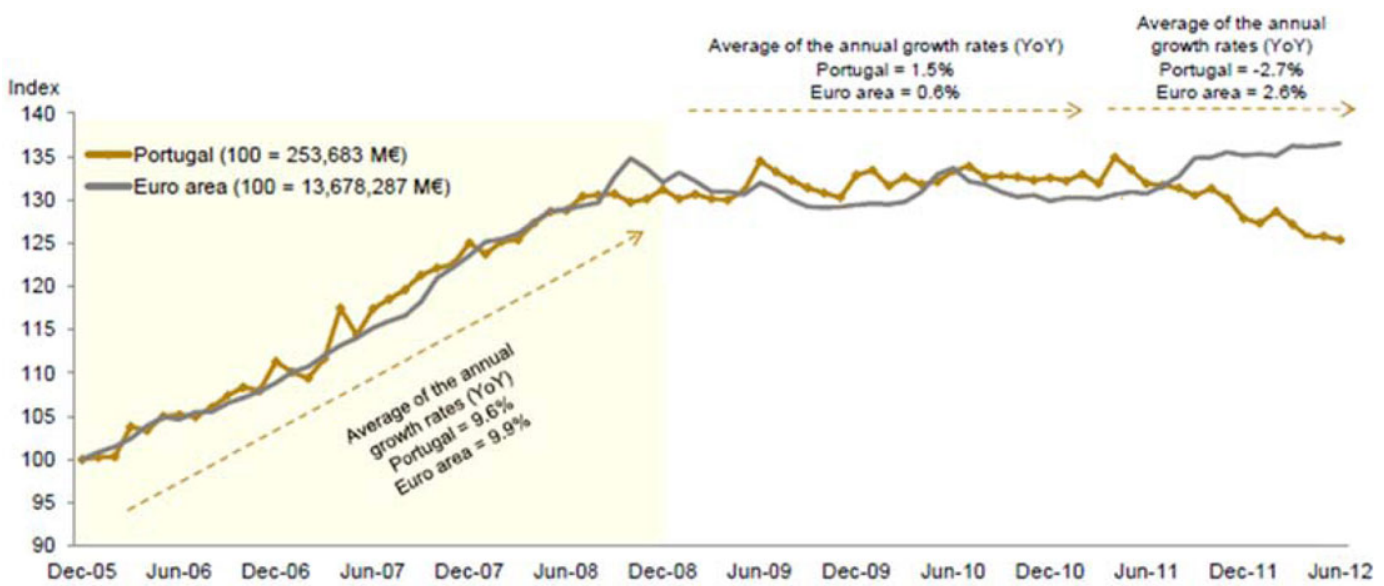

Figure 2 - Trends in credit in Portugal and in the euro area (Dec. $2005=100$ ) Source: Adapted from APB (2012a).

Figure 2 also shows that during the period that preceded the financial crisis, the credit volumes followed a strong increasing trend, both in Portugal and in the euro area. In the summer of 2008, credit growth slowed down, and, in Portugal, it started decreasing after the second quarter of 2011 (APB 2012a). This reduction in credit has been more significant for companies and personal loans, especially consumer and other credit. Smaller private, less capitalized companies are thought to have been the most affected by the banks' stricter requirements for lending. At the same time, the banking sector remained under pressure to meet the funding needs of state-owned companies, which explains the growth of loans to them (APB 2012b). Figure 3 presents the evolution of credit by institutional sector, in Portugal, in the 2005-2011 periods. The stocks of credit to households and non-financial corporations reveal divergent trends from those verified to the general Government. The agreement on a financial support programme for Greece in May 2010 seriously worsened the Portuguese Republic's conditions for obtaining financing through financial markets. In April 2011, when Portugal asked for international financial assistance, the credit volumes to the general Government reached their peak. Additionally, as state-owned entities accounted for almost $10 \%$ of the total debt of non-financial corporations to the resident financial sector in 2011 (against only $6 \%$ in 2006), the funding to the Portuguese economy was being swallowed up by public entities.

The same scenario is presented for financial investment portfolios. After a period of strong growth between 2008 and 2010, financial investments show a decrease in 2011, partly from the impairment of held-to-maturity investments, due to the statement of losses arising from the restructuring of Greece's sovereign debt and the fall in the share market that resulted in the recognition of impairment of shares held by banking institutions. In addition, despite the sale of some non-strategic assets due to deleveraging imperatives, banking institutions maintained a trend in favour of the acquisition of Portuguese public debt securities (APB 2012b). Indeed, in the first eight months of 2012, Portuguese banks increased their exposure to Portuguese sovereign debt at 7.4 billion euros (Bank of Portugal's Statistical Interactive Database). These applications 


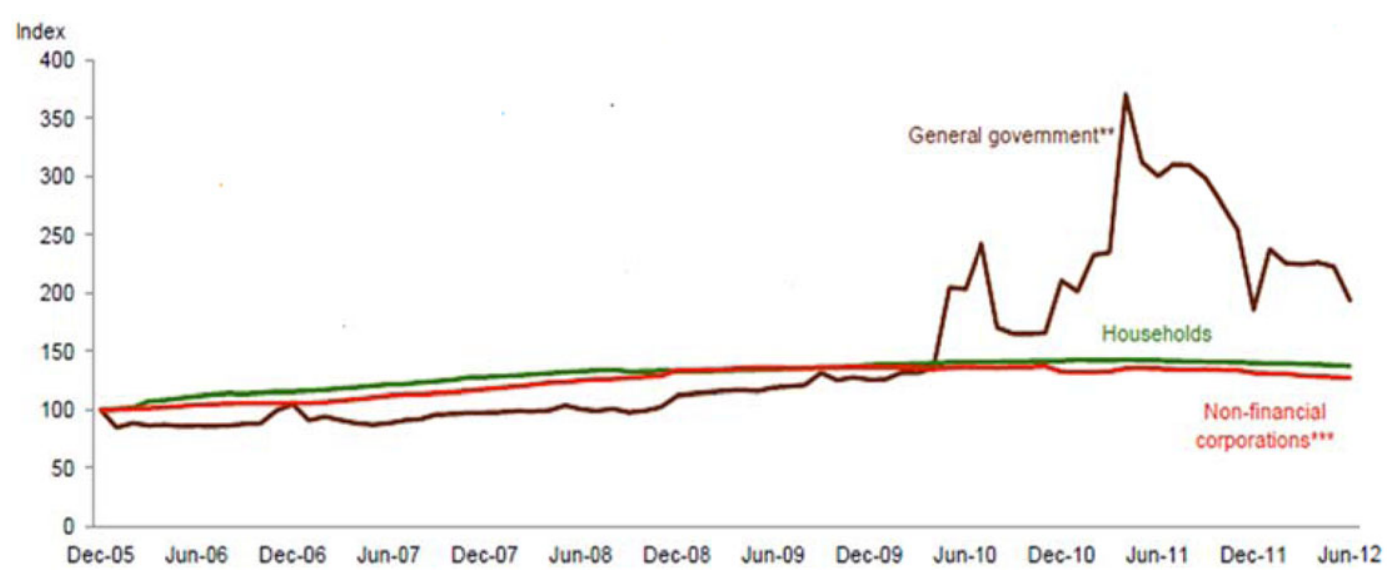

Figure 3 - Portuguese trends in credit by institutional sector (Dec. $2005=100$ ) Source: Adapted from APB (2012a).

were carried out with the objective of investment and not due to the need to ensure the financing of the state. In fact, of that amount, 5.4 billion euros were channelled into Treasury bonds, which meant that these titles would be acquired in the secondary market, given that Portugal has not issued debt in the medium and long term since April 2011.

Summing up, the Portuguese banking industry's lending and investment behaviour is under public scrutiny for political, economic and social reasons. In the next section, this behaviour is examined.

\section{The lending and investment behaviour of Portuguese banking}

\subsection{Methodology and data}

To assess the differences in the Portuguese credit institutions' lending and investment behaviour, a statistical analysis was conducted by comparing the sample means, complemented by the estimation of an empirical model.

The study of banks' lending and investment behaviour is based on the analysis of their business model (Köhler 2014). In general, business models describe how banks generate profits, which customers they serve and which distribution channels they use. The banking business model is reflected in the structure of their balance sheet (Paulet and Relano 2010), as shown in Table 3.

The present work makes use of this methodology and focuses the analysis on two items: clients' transactions and financial transactions. A higher percentage devoted to clients' transactions is typical of a retail-oriented bank. Moreover, the balance between the clients' transactions on the liabilities - deposits (savings) - side and the assets loans - side is a measure of the risk of the bank lending policy and is fairly characteristic of a cooperative and mutual savings bank rather than a universal institution. On the contrary, savings collection and project financing through loans are no longer the core 
Table 3 - Description of the balance sheet in four blocks

\section{Assets}

Interbank operations

Clients' transactions

Financial transactions

Reserves
Liabilities

Interbank operations

Clients' transactions

Financial transactions

Equity

Source: Paulet and Relano (2010)

business of institutions that achieve high scores in financial transactions; rather, their main field of activity is concentrated on the global financial market - investment banks.

For the analysis of the banks' credit and financial investment activity, three variables are used: loans-to-deposits ratio, loans to customers and financial investments (both as a percentage of the total assets). The former intends to reflect the banks' creditgranting policy and is a measure of its risk aversion and prudential behaviour. The second ones reflect the bank's strategy regarding fund applications and its business approach to banking activity. It is expected that significant differences between the different types of banks under study and throughout the time period analysed will be found. Table 4 presents the variables' definition.

\section{Table 4 - Variables' definition}

\begin{tabular}{ll}
\hline & Description \\
\hline $\begin{array}{l}\text { Loans-to-deposits ratio } \\
\text { Loans to customers }\end{array}$ & $\begin{array}{l}\text { Gross loans/deposits from customers } \\
\text { Loans to customers/assets } \\
\text { Financial investments }\end{array}$ \\
$\begin{array}{l}\text { (Financial assets held for trading + other assets at fair value through profit or loss + } \\
\text { available-for-sale financial assets + held-to-maturity investments and assets with } \\
\text { repurchase agreements)/assets }\end{array}$ \\
\hline
\end{tabular}

Prior to the comparison of the sample means, the data are tested for normality using the Shapiro-Wilk test and, whenever normality applies, the statistic $t$ test is used for comparisons of two samples and the one-way Anova is used for comparisons of more than two samples; if normality is violated, the Mann-Whitney test is conducted to compare two variables and the KrusKal-Wallis test is used to compare more than two samples. Having determined that differences exist among the samples, the Scheffe post hoc test is used to identify homogeneous subsets of means that are not different from each other. To minimize the type I and II errors, a significance level of 0.05 was adopted.

The empirical model assumes the linear regression form and it was constructed by the estimation of the following function:

$$
Y_{i, t}=F(\text { Cooperative, State, Saving, 2008_Crisis, 2011_EAP) }
$$

where $\mathrm{Y}_{\mathrm{i}, \mathrm{t}}$ is the loans-to-deposits ratio, loans to customers or financial investments of bank $i$ in year $t$; and the bank type (Cooperative, State and Saving), the 2008_Crisis and 2011_EAP are explanatory variables. As the type of bank is a qualitative variable that assumes four categories, three dummy variables were created (cooperative, state and saving): the variable cooperative assumes the value of 1 if the bank is a cooperative, 
Table 5 - Variables' statistics by type of bank

\begin{tabular}{|c|c|c|c|c|c|c|c|}
\hline & \multirow{2}{*}{$\mathbf{N}$} & \multicolumn{2}{|c|}{ Loans-to-deposits ratio } & \multicolumn{2}{|c|}{ Loans to customers } & \multicolumn{2}{|c|}{ Financial investments } \\
\hline & & Mean & Std deviation & Mean & Std deviation & Mean & Std deviation \\
\hline Cooperative bank & 13 & 0.8618 & 0.0270 & 0.6412 & 0.0616 & 0.1779 & 0.0999 \\
\hline State-owned bank & 13 & 1.2094 & 0.0761 & 0.6386 & 0.0287 & 0.2153 & 0.0124 \\
\hline Investor-owned bank & 39 & 1.5913 & 0.2438 & 0.6726 & 0.0644 & 0.1744 & 0.0553 \\
\hline Mutual savings bank & 13 & 1.6218 & 0.2157 & 0.7870 & 0.2002 & 0.1671 & 0.0695 \\
\hline \multirow{2}{*}{\multicolumn{2}{|c|}{$\begin{array}{c}\text { Statistic F } \\
\text { Significance }\end{array}$}} & \multicolumn{2}{|c|}{54.119} & \multicolumn{2}{|c|}{6.846} & \multicolumn{2}{|c|}{11.479} \\
\hline & & \multicolumn{2}{|c|}{0.000} & \multicolumn{2}{|c|}{0.000} & \multicolumn{2}{|c|}{0.000} \\
\hline
\end{tabular}

Note: Homogeneous subsets of means in $\longrightarrow$

while the variable state assumes the value of 1 in the case of a state-owned bank and the variable saving takes the value of 1 in the case of a mutual savings bank. The 2008_crisis variable measures the effects of the 2008 crisis and takes the value of 1 from 2009 until the first semester of 2011; the 2011EAP variable measures the adjustments made by banks under the 2011 EAP, taking the value of 1 after the first semester of 2011.

The sample includes data regarding a state-owned bank, three privately owned banks, a mutual savings bank and a cooperative banking system, holding more than $75 \%$ of the market share, overall. The data are collected from the company's half-yearly balance sheets, from June $2006^{4}$ to June 2012, i.e. 13 periods, a pool of 76 observations. The study period (2006-2011) was divided into 3 time periods: a) Period 1, which includes the data before the 2008 financial crisis (from 2006 to 2008); b) Period 2, which is from 2009 to the first semester of 2011; and c) Period 3, which encompasses the period subsequent to the 2011_EAP (after the second semester of 2011).

\section{$4.2 \quad$ Results}

The credit institutions studied present similar business models, with their core centred on retail banking (clients' transactions) but also operating in the financial market (financial transactions), although with different intensities. However, the cooperative bank is the only bank presenting a positive balance between the liabilities and the assets side for clients' transactions, meaning that savings collection is greater than loan distribution. The other banks show dominance of credit-granting activities over savings activities, even the mutual savings bank, despite its supposed saver profile. Table 5 presents a summary of the statistics of the variables loans-to-deposits ratio, loans to customers and financial investments by type of bank.

For the loans-to-deposits ratio, three significantly different groups were identified, including: a) cooperative banks; b) state-owned banks; and c) IOF and mutual savings banks. The cooperative bank presents a lower ratio of loans to deposits; on the contrary,

4 The data prior to 2006 obey the PCSB (Plano de Contabilidade do Sistema Bancário); the normalization of Portuguese credit institutions according to International Accounting Standards only took place in 2007. That change in the accounting system had a significant repercussion for the banking sector balance sheet and income statements, thus undermining any attempt to include the period before it in the analysis. 
investor-owned and mutual savings banks present a higher loans-to-deposits ratio; and the state-owned bank scores somewhere between the two. These results are in line with the expectations given the banks' different economic objectives, except for the mutual savings bank, for which the surprisingly high score of the loans-to-deposits ratio can be somewhat explained by the unique bond that this institution maintains with its associates-customers entailed in its mutuality nature. Cooperative and state-owned banks follow a more risk-adverse credit policy as the pressure for shareholders' profits is diluted by their economic nature and ownership characteristics. Conversely, an IOF bank experiences more pressure for shareholders' returns, compelling its management to engage in higher leveraging, riskier earning strategies.

For the loans to customers and financial investments variables, two different statistically significant groups were identified: a) cooperative, state-owned and IOF banks; and b) mutual savings banks. Mutual savings banks dedicate a higher percentage of their assets to loans to customers and a lower percentage to financial investments when compared with their counterparts. On the other hand, cooperative, state and IOF banks dedicate a lower percentage of their assets to loans to customers and a higher percentage to financial investments. This is a surprising result for cooperative and state-owned banks, particularly concerning the financial investments variable for cooperative banks. Indeed, although savings banks' legal restrictions on financial investments can explain the difference regarding investor and state-owned banks (savings banks can only invest in companies listed on the Portuguese stock market, limited to $15 \%$ of deposits except for public debt), cooperative banks face similar restrictions. ${ }^{5}$ Cooperative banks ought to be different from universal banks, namely because of their history and values. The specific way in which cooperative banks are organized, their particular system of governance and the ultimate goals and underlying principles sustaining their activity are especially divergent from those of stockholder banks. The problem is that this fundamental difference between universal and cooperative banks is becoming diluted over time. For all banks, their net income is now seen as one of the best indicators of success and increasing the market share has become a full-time obsession. It seems as if the present-day macroeconomic context obliges banks to choose between cooperation or competition, traditional values or economic efficiency (Paulet and Relano 2010).

This gap between the promises of cooperative banks and what they actually achieve is confirmed by an inspection of their balance sheet. A loans-to-deposits ratio less than 1 reflects that savings collection from customers is more important than loan distribution. Cooperative (and mutual) banks usually function in this way. However, as far as the transactions in the financial market are concerned, the percentages shown by the mutual savings bank are clearly lower than those shown by the other types of bank, even though they are not negligible either. This evidences that for mutual savings banks, trading on the stock market is not the core of their business. Nevertheless, they will not hesitate to carry out certain operations on the financial market to improve their profitability. On the other hand, a comparative analysis of the balance sheets of IOF

$5 \quad$ They can only make applications in public debt in conditions established by the Bank of Portugal and hold participations: a) in regional unions, Central Credit Cooperative and National Federation of Credit Cooperatives; b) in enterprises whose object is of regional interest (until 20\% of own funds); c) to assure the reimbursement of credits; and (d) when especially authorized by the Bank of Portugal. 
and cooperative banks shows no statistically significant differences as regards the core of their business model. While their main activity is focused on the traditional activities of granting credit, both banks make ample use of financial markets' businesses.

When testing for changes in the variables due to the 2008 financial crisis and the 2011 EAP (Table 6), for a significance level of 5\%, no statistically significant differences are found among the time periods for the variable loans-to-deposits ratio. Indeed, although a decrease is observed in the loans-to-deposits ratio throughout the time periods under study, those alterations are not statistically significant. For the loans to customers and financial investments variables, statistically significant differences are found among the time periods considered; the post hoc tests grouped them into two homogeneous subsets of means that are not different from each other: a) Periods 1 and 2, and $\mathrm{b}$ ) Period 3, for the loans to customers variable; a) Period 1, and b) Periods 2 and 3 , for the financial investments variable.

Table 6 - Variables' statistics by time periods

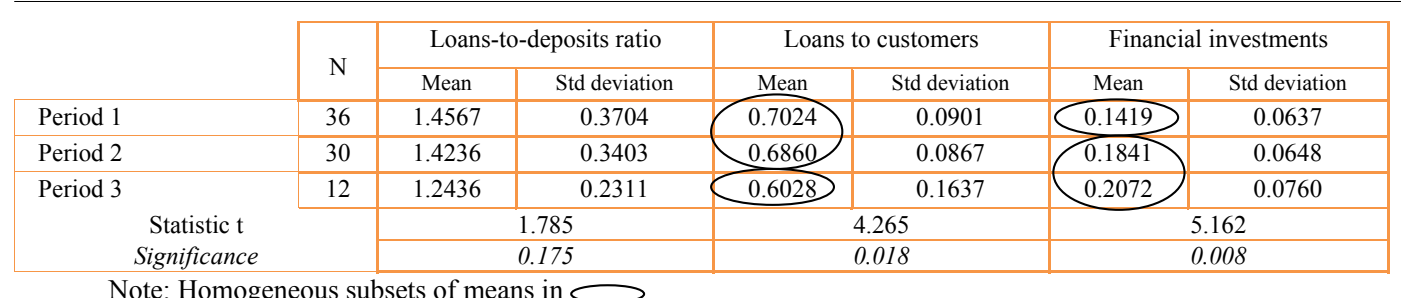

Note: Homogeneous subsets of means in $\longrightarrow$

Overall, after the 2008 crisis, Portuguese banks began to dedicate a smaller proportion of their assets to loans to customers; however, that decrease was only statistically significant after the $2011 \mathrm{EAP}$, which can be explained by the deleveraging process initiated under the programme mentioned. Additionally, following the 2008 financial crisis, in general, Portuguese credit institutions changed their behaviour in favour of financial investments; thus, in the periods posterior to 2008, they set aside a high proportion of their assets for operations in the financial market. This result gives credit to the popular belief that banks are making a fortune from the sovereign debt crisis given the impossibility of ECB funding states directly, which compels them to submit to the sovereign debt market speculation, gaining fatter banks, once they are buying (with ECB money) the debt of states as then the ECB, in turn, buys it from them. It is necessary, however, to be cautious in accepting this conclusion, as will be explained below.

When the changes in the variables are tested during the time periods by type of bank $^{6}$ (Table 7), the results show that there are differences between the time periods, regarding the variable loans-to-deposits ratio for IOF and mutual savings banks; regarding the variable loans to customers for cooperative and mutual savings banks; and with regard to the variable financial investments for cooperative and mutual savings banks. Moreover, the analysis shows that the loans-to-deposits ratio variable experienced a decrease during the study period, except for the cooperative banks type. This change is statistically significant for the IOF, cooperative and mutual savings banks types. For the

6 These results should be considered carefully because the groups' size is small, with a high probability of type I error occurrence. 
Table 7 - Variables' statistics by time period and type of bank

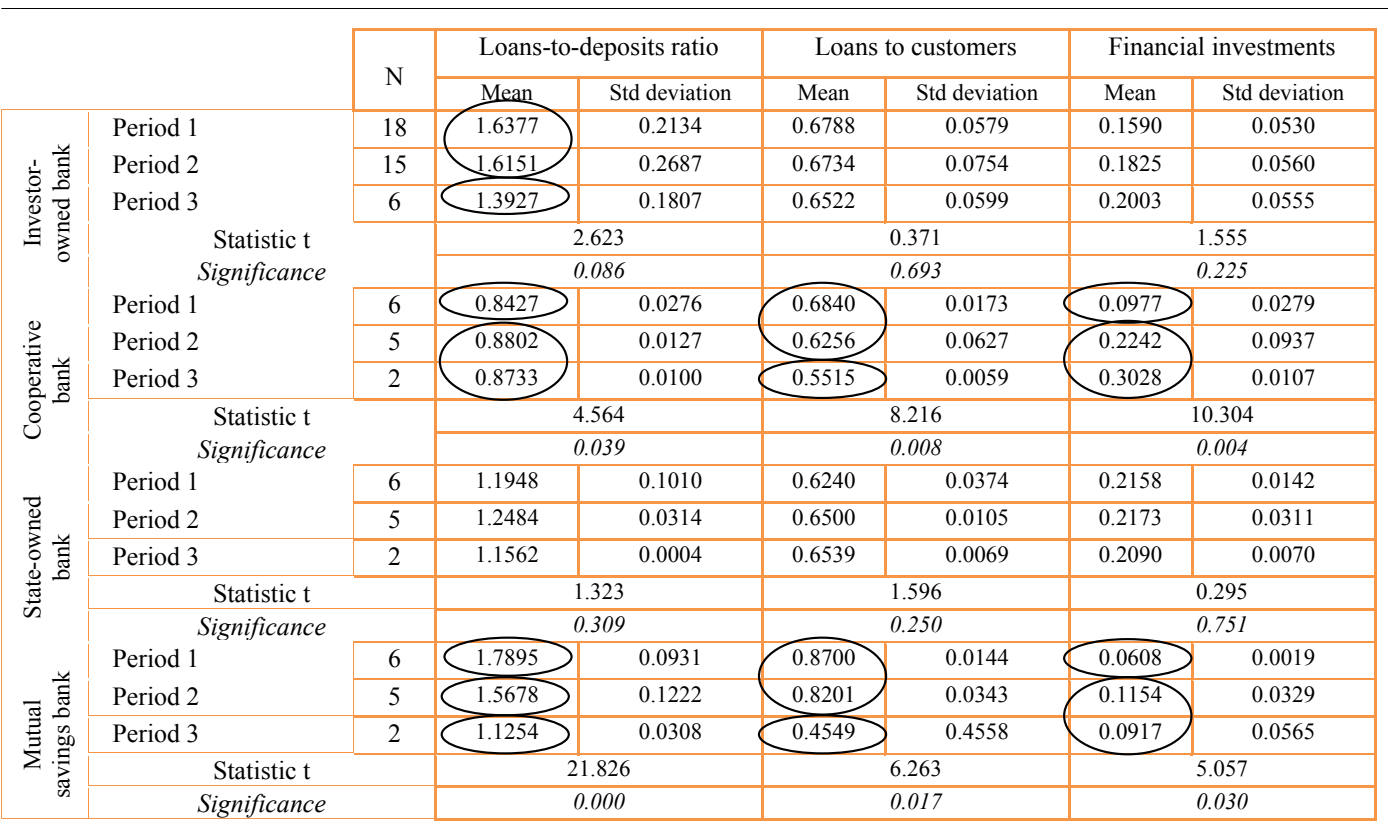

Note: Homogeneous subsets of means in $\longrightarrow$

investor-owned bank type, two groups are identified -: a) Period 1, and b) Periods 2 and $3-$, meaning that the 2008 crisis effects have a deeper statistically significant impact on this variable than the limit for the transformation ratio imposed by the 2011 EAP. For mutual savings banks, three groups were identified. It should be take into consideration that this type of bank is the one that presents the high original value for that variable, so the adjustments generated by the 2008 crisis effects and 2011 EAP requirements were more expressive here than in the other types of banks. The cooperative banks present a different evolution and, overall, the loans-to-deposits ratio shows an increase during the study periods, identifying two statistically different groups: a) Period 1; and b) Periods 2 and 3. Historically, cooperative banks have a conservative lending policy with a transformation ratio below 0.9 (Cabo 2012); the increase in market competition for customers' deposits as a result of the Portuguese credit institutions' difficulty in accessing capital markets can be the origin of this evolution. Accordingly, it is worth mentioning the concern of a cooperative bank leader regarding the battle for deposits in Portuguese banking, questioning the sustainability of the deposit rates offered and its effect on the sector's profitability (Expresso 2012). This situation forced, in November 2011, the intervention of the Portuguese supervisor, the Bank of Portugal, by imposing a limit on the deposit interest rates offered by banks, penalizing the core tier 1 capital ratio of the institutions that overlapped that boundary (Banco de Portugal 2011).

In general, the variable loans to customers experienced a decrease during the study period, except for the state-owned bank type, although it is not statistically significant. The cooperative and mutual savings banks both present a statistically significant reduction between Period 2 and Period 3, indicating that the 2011 EAP had a deeper impact on these banks' activity than the 2008 crisis. 
Overall, the variable financial investments experienced an increase during the study period, except for the state-owned bank type, although it is not statistically significant. The cooperative and mutual savings banks present statistically significant differences between the time periods under study, identifying two homogeneous subsets of means: a) Period 1; and b) Periods 2 and 3. As mentioned, this finding gives credit to the popular belief that banks are making a fortune from the sovereign debt crisis. However, it must be remembered that for cooperative banks, 2009 was a turning point, as their new legal regime, approved in that year, introduced major alterations into cooperative banks' business activity, namely by allowing individual cooperative banks, once complying with prudential requirements, to perform several operations that had been outlawed in the past, in conditions similar to those of universal banks (Cabo 2012).

Table 8 includes the results of the estimation of the linear regression model. According to the value of the statistic $\mathrm{F}$, in the three models, the set of the explanatory variables is globally significant, corresponding to the expected results, given the preceding statistical analysis.

Table 8 - Linear regression model results

\begin{tabular}{|c|c|c|c|c|c|c|}
\hline & \multicolumn{2}{|c|}{ Model 1} & \multicolumn{2}{|c|}{ Model 2} & \multicolumn{2}{|c|}{ Model 3} \\
\hline & \multicolumn{2}{|c|}{ Loans-to-deposits ratio } & \multicolumn{2}{|c|}{ Loans to customers } & \multicolumn{2}{|c|}{ Financial investments } \\
\hline & $\beta$ & Std error & $\beta$ & Std error & $\beta$ & Std erro \\
\hline Constant & $1.637^{*}$ & 0.037 & $0.694^{*}$ & 0.018 & $0.149^{*}$ & 0.011 \\
\hline Cooperative bank & $-0.729 *$ & 0.059 & -0.031 & 0.029 & 0.003 & 0.017 \\
\hline State-owned bank & $-0.382^{*}$ & 0.059 & -0.034 & 0.029 & $0.041 * *$ & 0.017 \\
\hline Mutual savings bank & 0.030 & 0.059 & $0.114^{*}$ & 0.029 & $-0.088^{*}$ & 0.017 \\
\hline 2008_crisis & -0.033 & 0.046 & -0.016 & 0.023 & $0.042^{*}$ & 0.013 \\
\hline 2011_EAP & $-0.213^{*}$ & 0.062 & $-0.100 *$ & 0.031 & $0.059 *$ & 0.018 \\
\hline Statistic F & \multicolumn{2}{|c|}{$39.401^{*}$} & \multicolumn{2}{|c|}{$6.757^{*}$} & \multicolumn{2}{|c|}{$11.249^{*}$} \\
\hline$R^{2}$ & \multicolumn{2}{|c|}{0.732} & \multicolumn{2}{|c|}{0.319} & \multicolumn{2}{|c|}{0.439} \\
\hline
\end{tabular}

*Significance level of $1 \%$; ** significance level of $5 \%$.

For model 1, the variables cooperative and state-owned banks and 2011_EAP present (negative) estimators that are statistically significant at the $1 \%$ significance level, thus proving to have a significant effect on the variable loans-to-deposits ratio. Specifically, the value of -0.729 for the cooperative bank estimator indicates that the difference in the loans-to-deposits ratio between the cooperative banks and the other bank types is -0.729 , ceteris paribus. Thus, for the same time period (and other factors influencing the loans-to-deposits ratio), cooperative banks present a lower loans-to-deposits ratio than other types of banks. The same is true for the case of state-owned banks, although their influence is smaller (-0.382). Finally, the 2011_EAP variable also proved to influence the loans-to-deposits ratio negatively as, keeping other factors influencing the loans-to-deposits ratio constant, it takes a lower score $(-0.213)$ for the period following the 2011 EAP.

For model 2, only the variables mutual savings bank and 2011_EAP show the estimators to be statistically significant at the $1 \%$ level of significance. The estimator for the dummy explanatory variable mutual savings bank has a positive value (of 0.114), meaning that mutual savings banks set aside a higher proportion of their assets for loans 
to customers than other types of banks. Moreover, the 2011_EAP variable proved, as in model 1, to influence the dependent variable negatively, i.e., all other factors remaining constant, in the 2011 EAP period, the loans to customers were lower than in other periods.

For model 3, the variables mutual savings and state-owned banks and the variables 2008_crisis and 2011_EAP present estimators that are statistically significant at the $1 \%$ significance level, thus proving to have a significant effect on the variable financial investments. For the explanatory variable mutual savings banks, the effect is negative (-0.088), indicating that this type of bank dedicates a lower proportion of its assets to financial investments than other types of banks. The positive estimator of the state-owned variable indicates that this type of bank allocates a higher proportion of its assets to financial investments than other types of banks, although it is a smaller absolute standardized coefficient, indicating that it contributes less to the model. The time period variables both present positive values for the estimators, proving that the 2008 crisis and 2011 EAP had the effect of increasing the relative importance of financial investments assets to the banks' activity.

\section{Conclusion}

In general, it may be concluded that universal (IOF and state-owned) and cooperative and mutual savings banks' lending and investment behaviour in a time of crisis only differ in terms of the quantitative percentage of their different banking activities, but the overall business models applied are qualitatively identical. Ultimately, they are not that different. Even if mutual and cooperative banks continue to claim that they share fundamental values that make them a very special kind of financial institution, the figures show that in their day-to-day practice, they are quite similar to their universal counterparts. The main differences in their business models are the clear saver profile of cooperative banks and the deeper focus on loans to customers to the detriment of financial investment activities by the mutual savings bank.

Regarding the change in behaviour as a result of the particularly difficult circumstances of the Portuguese economy, the only type of institution that presented the desirable evolution, although the change was not deep enough to be statistically significant, was the state-owned bank type. The other credit institutions' changes do not follow the public opinion requests or their own marketing discourse.

The short period of the analysis is a disadvantage and shortcoming for which future investigation, able to widen it, will increase the findings' robustness. Further research can also complement this study's findings, namely by analysing credit institutions' credit and financial investments portfolio and including non-domestic credit institutions.

\section{REFERENCES}

APB, 2012a, 'Banca, Supervisão e Financiamento da Economia', X Forum da Banca, Associação Portuguesa de Bancos, Lisboa (Portuguese Association of Banks).

APB, 2012b, Boletim Informativo No 47 2011, Lisboa, Associação Portuguesa de Bancos. 
APB, 2012c, Perspectiva Sobre o Sistema Bancário, Lisboa, Associação Portuguesa de Bancos.

BANCO DE PORTUGAL, 2011, Instrução 28/2011, Lisboa, Banco de Portugal.

BECK T., HESSE H., KICK T. and VON WESTERNHAGEN N., 2009, Bank ownership and stability, Mimeo.

BENSTON G. and SMITH C., 1976, 'A transaction cost approach to the theory of financial intermediation', Journal of Finance, 31, 215-231.

BERTAY A.C., DEMIRGÜÇ-KUNT A. and HUIZINGA H., 2012, Bank ownership and credit over the business cycle: Is lending by state banks less procyclical? CEPR Discussion Paper No. 9034.

BOOT A.W.A., 2000, 'Relationship banking: What do we know?', Journal of Financial Intermediation, 9, 7-25.

BOSCIA V. and DI SALVO R., 2009, 'The theory and experience of cooperative banking', in V. Boscia, A. Carretta and P. Schwizer, eds., Cooperative Banking: Innovations and Developments, Palgrave Macmillan Studies in Banking and Financial Institutions.

BUNGER D., 2009, Bank ownership structure and performance: an analysis of cooperative and mutual savings banks, The Arthur Levitt Public Affairs Center, manuscript.

CABO P. 2012, Essays on governance and failure of co-operative banks: the portuguese agricultural credit co-operatives, PhD Thesis, University of Trás-os-Montes and Alto Douro, Portugal.

CUEVAS C. and FISHER K., 2006, 'Cooperative financial institutions', World Bank Working Paper \# 82.

DE BRUYN R. and FERRI G., 2005, 'Le ragioni delle banche popolari: motivi teorici ed evidenze empiriche', in R. De Bruyn and G. Ferri, eds., Le Banche Popolari nel localismo dell'economia italiana, Rome, Edicred.

EXPRESSO, 2012, 'Estão a ser praticados excessos nos depósitos', Expresso, 23rd February 2012.

FERRI G., KALMI P. and KEROLA E., 2014, 'Does bank ownership affect lending behavior? Evidence from the Euro area', Journal of Banking and Finance, 48, 194209.

FONTEYNE W., 2007, 'Cooperative Banks in Europe - Policy Issues', IMF Working Paper WP/07/159.

FUNGÁČOVÁ Z., HERRALA R. and WEILL L., 2013, 'The influence of bank ownership on credit supply: Evidence from the recent financial crisis', Emerging Markets Review, 15, 136-147.

GAMBACORTA L. and MISTRULLI P.E., 2004, 'Does bank capital affect lending behaviour?', Journal of Financial Intermediation, 13, 436-457.

HESSE H. and CIHÁK M., 2007, 'Cooperative banks and financial stability', Washington, IMF Working Paper.

GOODHART C., 1989, Money, Information, and Uncertainty, London, Macmillan.

KANE E. and HENDERSHOTT J., 1996, 'The federal deposit insurance fund that didn't put a bite on U.S. taxpayers', Journal of Banking and Finance, 20, 1305-1327. 
KÖHLER M., 2014, 'Which banks are more risky? The impact of business models on bank stability', Journal of Financial Stability (forthcoming). Available at SSRN: http://ssrn.com/abstract=2180688 or http://dx.doi.org/10.2139/ssrn2180688.

MICCO A. and PANIZZA U., 2006, 'Bank ownership and lending behavior', Economics Letters, 93, 248-254.

PAULET E. and RELANO F., 2010, 'The twofold betrayal of co-operative banking', in ICA European Research Conference: 'Co-operatives Contributions to a Plural Economy', Lyon, France.

PETERSEN M.A. and RAJAN R.G., 1994, 'The benefits of lending relationships: evidence from small business data', Journal of Finance, 49(1), 3-37.

SAPIENZA P., 2004, 'The effects of government ownership on bank lending', Journal of Financial Economics, 72, 357-384.

STIGLITZ L., 1990, 'Peer monitoring in credit markets', World Bank Economic Review, $4,351-366$. 